DOI: https://doi.org/10.24297/jbt.v8i0.8062

\title{
Micropropagation and Ex Situ Conservation of Silene Fabaria (L.) Sm. in Sibth. \& Sm. Subsp. Domokina Greuter (Caryophyllaceae); An Important Endemic Plant in Greece With Medicinal and Ornamental Value
}

\author{
Virginia Sarropoulou*, Eleni Maloupa
}

Hellenic Agricultural Organization (HAO)-DEMETER, Institute of Plant Breeding and Genetic Resources, Laboratory of Protection and Evaluation of Native and Floriculture Species, Balkan Botanic Garden of Kroussia, P.C. 57001 Thermi, Thessaloniki, Greece

vsarrop@gmail.com, maloupa@bbgk.gr

\begin{abstract}
Silene species (Caryophyllaceae) are sources of important secondary metabolites with extensive use in traditional medicine and potential applications as ornamentals. The present study was conducted to assess the regeneration potential of Silene fabaria subsp. domokina to produce massive clonal in vitro plants. Two experiments were conducted. The basal culture medium used was the MS. In the first experiment, the effect of 3 cytokinins; BA, KIN and 2-ip applied alone and in combination with 3 auxins; IBA, NAA and IAA was studied. In the second experiment, the effect of 3 auxins; IBA, NAA and IAA, each applied in 3 different concentrations $(0.1,0.25$ and $0.5 \mathrm{mg} / \mathrm{l})$ was studied. Shoot proliferation $100 \%$, highest shoot proliferation rate (4.83) and shoot number (3.67) were achieved with $0.25 \mathrm{mg} / \mathrm{I} \mathrm{BA}$ and $0.1 \mathrm{mg} / \mathrm{l} \mathrm{IAA}$ (5 weeks). IAA at $0.5 \mathrm{mg} / \mathrm{l}$ was the most effective in stimulating shoot elongation $(80.63 \mathrm{~mm})$. Rooting $100 \%$ was obtained with $0.1 \mathrm{mg} / \mathrm{l} \mathrm{IBA}$ yielding 7.3 roots $22.91 \mathrm{~mm}$ long (4 weeks). In vitro plants were successfully acclimatized with $92.31 \%$ survival rate. This study is the first micropropagation report of $S$. fabaria subsp. domokina that could be exploited for rapid, large-scale production and future germplasm maintenance of this valuable prioritized species-subspecies.
\end{abstract}

Indexing Terms/Keywords: Caryophyllaceae, Ex Situ Conservation, Germplasm Preservation, Greek Flora, Micropropagation, Silene fabaria subsp. domokina

\section{Introduction}

One of the aims of Global Strategy for Plant Conservation is the ex situ collection of at least the $60 \%$ of plant species threatened with extinction exhibiting a safeguarding role [1]. The temperate regions of the Northern Hemisphere are the natural habitat of species that belong to the Silene genus [2]. Silene L. is a promising genus for extensive use as a landscape ornamental due to its drought tolerance, profuse flowering and perennial characteristic [3]. Several species of Silene L., a genus of the Caryophyllaceae, have been recognized as ornamental plants suitable for rock gardens, herbaceous borders, and naturalized areas [4]. In Greece alone (major centre of the genus diversity) [2], 136 Silene species and subspecies are presently found, of which 53 are endemic to the country $[5,6]$.

A number of Silene species have been used in traditional medicine to treat inflammations, bronchitis, cold and infections or as a diuretic, antipyretic, analgesic and emetic [7-13]. Defense compounds including a variety of secondary metabolites are products of the Silene genus which are implicated in plant protection against microbes and herbivores $[14,15]$.

Silene fabaria (L.) Sm. in Sibth. \& Sm. subsp. domokina Greuter (Caryophyllaceae) is a perennial herbaceous plant with erect stems, whitish flowers and purplish filaments and somewhat fleshy, elliptic-obovate, glaucous leaves (possibly edible), which occurs predominately on serpentine (also on flysch) and with a flowering period to be extended from April to August [16]. It is a range-restricted Greek endemic subspecies with disjunct distribution only in three out of 13 phytogeographical regions of Greece i.e. small parts of South Pindos, East Central Greece 
(Mt Geraneia) and Sterea Hellas (Domokos area) $[5,6]$. This neoendemic taxon shows a disjunct distribution between the serpentine parts around the town of Domokos and the north-west serpentine slopes of Mt. Gerania (Greuter 1995). Except of serpentine predominately habitats, disturbed alluvia and scree along road embankments constitute the secondary man-made habitats in which this plant species exists [17].

Ex situ conservation of rare, endemic and endangered plants through in vitro culture techniques has been of high significance during time $[18,19]$. In vitro culture of some Silene species such as micropropagation of $S$. cretacea [20], a Silene hybrid (S. polypetala $\times$ S. virginica) [21] and S. sangaria [22], suspension cultures of $S$. vulgaris [23], shoot regeneration of $S$. vulgaris $[24,25]$ and S. thymifolia [26] have been described previously.

According to North et al. [27], the concentration and combination of auxins and cytokinins in the culture medium is a critical parameter which determines the efficiency of plant regeneration. Therefore, for successful in vitro propagation of $S$. fabaria ssp. domokina is essential to study the optimum combination of cytokinins and auxins as well as their interaction in the culture medium with respect to their concentrations for maximal shoot proliferation and/or rooting response.

To date, there has been no report on the in vitro culture of S. fabaria ssp. domokina and therefore the aim of the current study was the development of a mass regeneration in vitro protocol for conservation of genetic resources and safeguard inheritance for future generations.

\section{Materials and Methods}

\section{Plant material collection}

Plant material was collected from the natural habitats of the selected species. Plant material (living plants) was collected from ophiolithic screes of Omvriaki mining area (Domokos, Sterea Hellas), at an altitude of $500 \mathrm{~m}$ above sea level during a botanic expedition conducted (accession number GR-BBGK-1-98,456 linked with site description, habitat information and treatments received). In total, six plant individuals were placed in $1.5 \mathrm{~L}$ pots right after collection and were transferred at the Balkan Botanic Garden of Kroussia-Laboratory for the Conservation and Evaluation of Native and Floricultural Species (Institute of Plant Breeding and Genetic Resources, Hellenic Agricultural Organization Demeter) for immediate care to recover from transplanting shock.

\section{Plant material and in vitro culture conditions}

For the initial establishment of the plant material in vitro, shoot tips of $S$. fabaria subsp. domokina, 1-1.5 cm long were dissected and removed from mother plants maintained in a peat:perlite (1:1) substrate in pots under unheated-greenhouse conditions. For the disinfection of plant material, shoot tip explants were soaked in 70\% ethanol for $1 \mathrm{~min}$ followed by $2.5 \% \mathrm{NaOCl}$ solution for $15 \mathrm{~min}$ with agitation and rinsed for $4-5$ times with sterile distilled water. The basal culture medium used for the initial establishment phase was the Murashige and Skoog (MS) [28] supplemented with $30 \mathrm{~g} / \mathrm{l}$ sucrose (Duchefa, The Netherlants), $0.25 \mathrm{mg} / \mathrm{l}$ benzyladenine (BA), $0.1 \mathrm{mg} / \mathrm{l}$ indole-3-butyric acid (IBA), $0.1 \mathrm{mg} / \mathrm{l}$ gibberrelic acid $\left(\mathrm{GA}_{3}\right)$ and solidified with $6 \mathrm{~g} / \mathrm{l}$ Plant Agar (Duchefa, The Netherlands). The successfully established explants (pathogen-free) were sub-cultured every 4 weeks and for 3 successive times ( 3 continuous months) in the above medium until a sufficient plant material to be produced. The proliferated plant material was transferred into a hormone-free MS culture medium for 3 weeks prior experimentation.

The experimental material used was shoot-tip explants of 2.5-3.5 long obtained from previous in vitro cultures. Two experiments were conducted. In the first experiment, the effect of 3 different cytokinins; BA, kinetin (KIN) and 2-isopentenyladenine (2-ip), each applied at $0.25 \mathrm{mg} / \mathrm{l}$ in combination with 3 different auxins; IBA, $\alpha$ naphthaleneacetic acid (NAA) and indole-3-acetic acid (IAA), each applied in 3 different concentrations $(0,0.05$ and $0.1 \mathrm{mg} / \mathrm{l})$ on shoot proliferation ability was studied. The control treatment was devoid of plant growth regulators (cytokinin- and auxin-free). The basal culture medium used was the MS supplemented with $30 \mathrm{~g} / \mathrm{l}$ sucrose and solidified with $7 \mathrm{~g} / \mathrm{l}$ Plant Agar. The $\mathrm{pH}$ value of the culture media was adjusted to 5.8 before adding 
the gelling agent and afterwards the media were sterilized in autoclave at $121^{\circ} \mathrm{C}$ for $20 \mathrm{~min}$. Shoot-tip explants were transferred into Magenta vessels containing $35 \mathrm{ml}$ of MS medium. All cultures were maintained in a growth chamber with a 16 -h light duration $\left(40 \mu \mathrm{mol} / \mathrm{m}^{2} / \mathrm{s}\right)$ supplied by cool white fluorescent lamps and a constant temperature of $22 \pm 2{ }^{\circ} \mathrm{C}$. After 5 weeks of culture, the following measurements were recorded: shoot number/explant, shoot length $(\mathrm{mm})$, shoot multiplication percentage $(\%)$, shoot proliferation rate, root number/rooted microplant, root length $(\mathrm{mm})$ and rooting percentage (\%). In the second experiment, the effect of 3 different auxins; IBA, NAA and IAA, each applied in 3 different concentrations $(0.1,0.25$ and $0.5 \mathrm{mg} / \mathrm{l})$ on rooting ability was studied. The control treatment was auxins-free. The basal culture medium used was the MS supplemented with $20 \mathrm{~g} / \mathrm{l}$ sucrose and solidified with $6 \mathrm{~g} / \mathrm{l}$ Plant Agar. The $\mathrm{pH}$ value of the culture media was adjusted to 5.8 before adding the gelling agent and afterwards the media were sterilized in autoclave at $121^{\circ} \mathrm{C}$ for $20 \mathrm{~min}$. Shoot-tip explants were transferred into Magenta vessels containing $35 \mathrm{ml}$ of MS medium. All cultures were maintained in a growth chamber with a 16 -h light duration $\left(40 \mu \mathrm{mol} / \mathrm{m}^{2} / \mathrm{s}\right)$ supplied by cool white fluorescent lamps and a constant temperature of $22 \pm 2{ }^{\circ} \mathrm{C}$. After 4 weeks of culture, the following measurements were recorded: root number/rooted microplant, root length $(\mathrm{mm})$, rooting percentage (\%), shoot number/explant, shoot length $(\mathrm{mm})$, shoot multiplication percentage $(\%)$ and shoot proliferation rate.

\section{Ex vitro acclimatization of rooted in vitro plants}

In mid-February 2018, obtained rooted microplants with well-developed shoots were washed with running tap water and transferred to a peat moss (Terrahum): perlite (Geoflor) (1:1 v/v) substrate. The plantlets were transferred onto 84-position trays and placed on a bench plastic tunnel with adjustable relative humidity (internal mist system), with $65-72 \%$ relative humidity for 4 weeks, under unheated greenhouse conditions. In mid-March 2018, the successfully acclimatized plants were transplanted into larger pots $(0.33 \mathrm{Lt}-8 \times 8 \times 7 \mathrm{~cm})$ containing a more enriched in organic matter substrate mixture of peat moss (TS2, Klassmann): perlite (Geoflor): soil $(2: 1 / 2: 1 / 2 \mathrm{v} / \mathrm{v}$ ratio) and placed onto a greenhouse bench (50 $\pm 5 \%$ relative humidity) for 7 more weeks (until mid-May) and irrigated by an automatic sprinkling system. The plants were transplanted afterwards into pots of $2.5 \mathrm{~L}$ containing a peat moss (TS2): perlite: soil substrate $(2: 1 / 2: 1 / 2 \mathrm{~V} / \mathrm{V}$ ratio) and maintained in the same greenhouse for another 2 weeks (until the end of May) where irrigation was provided manually when was necessary depending on environmental conditions. The first week of June, the potted plants were transferred outdoors in the nursery and observations were taken after a period of 3 weeks (end of June). Data were obtained after 16 weeks (from rooted microplants to fully acclimatized) and their survival percentage was recorded.

\section{Statistical analysis}

Both experiments were completely randomized and analyzed with ANOVA (Analysis of Variance) using the statistical program SPSS 17.0 (SPSS Inc., Illinois, New York, USA) at $P \leq 0.05$, according to Duncan's multiple range test \pm SE in order significant differences among treatments to be established.

The first experiment included 22 treatments with 12 replicates ( 3 Magenta vessels $\times 4$ explants each). The experiment was a $3 \times 3 \times 3$ factorial one with 3 different cytokinin types (BA, KIN, 2-ip), 3 different auxin types (IBA, NAA, IAA) and 3 different auxin concentrations $(0,0.05,0.1 \mathrm{mg} / \mathrm{l})$ and the control without auxins, without cytokinins and none plant growth regulators. The effect of the main factors (i) cytokinin type, (ii) auxin type (iii) auxin concentration and their interactions were determined by the General Linear Model (3-way ANOVA).

The second experiment included 10 treatments with 16 replicates (4 Magenta vessels $x 4$ explants each). The experiment was a $3 \times 3$ factorial one with 3 different auxin types (IBA, NAA, IAA) and 3 different auxin concentrations $(0.1,0.25,0.5 \mathrm{mg} / \mathrm{l})$ and the control without auxins. The effect of the main factors (i) auxin type, (ii) auxin concentration and their interaction were determined by the General Linear Model (2-way ANOVA).

\section{Results}

In the present study, $90.91 \%$ pathogen-free plant material was recorded after 4 weeks in culture, following disinfection with $70 \%$ ethanol for $1 \mathrm{~min}$ and $2.5 \% \mathrm{NaOCl}$ solution for $15 \mathrm{~min}$ with agitation. Within a 3-month 
period of continuous sub-culturing the explants in the initial establishment medium of $0.25 \mathrm{mg} / \mathrm{l} \mathrm{BA}, 0.1 \mathrm{mg} / \mathrm{l}$ IBA and $0.1 \mathrm{mg} / \mathrm{l} \mathrm{GA}$ there was an extremely rapid increase in the number of produced explants, from the 15 initial explants to a total of 200 shoot tips.

In the first experiment, the best shoot proliferation treatment was the combination of $0.25 \mathrm{mg} / \mathrm{l}$ BA with $0.1 \mathrm{mg} / \mathrm{l}$ IAA, yielding 100\% shoot formation percentage, 3.67 shoots/explant, $36.37 \mathrm{~mm}$ average shoot length and 4.83 shoot proliferation rate for all explants used in this treatment (Figure 1h). However, the longest shoots (66.45 $\mathrm{mm}$ ) were obtained in the control, in a medium without plant growth regulators (Figure 1a). Shoot proliferation $100 \%$ was recorded in the additional 3 treatments: $0.25 \mathrm{mg} / \mathrm{l} \mathrm{BA}$ (Figure 1b), $0.25 \mathrm{mg} / \mathrm{l} \mathrm{BA}$ with $0.05 \mathrm{mg} / \mathrm{l} \mathrm{IBA}$ (Figure 1c) and $0.25 \mathrm{mg} / \mathrm{l} \mathrm{BA}$ with $0.05 \mathrm{mg} / \mathrm{l} \mathrm{NAA}$ (Figure 1e). The application of BA alone and in combination with all 3 auxin types (IBA, NAA, IAA) in the culture medium considerably increased (approximately by 3.5-4.5 times) shoot proliferation rate (3.25-4.83) in relation to the control's. The other 2 cytokinins (KIN and 2-ip), on the other hand, applied either alone or with auxins gave similar shoot proliferation rates $(0.21-1.88)$ to the control's (0.93), except for the $0.25 \mathrm{mg} / \mathrm{l} 2$-ip $+0.1 \mathrm{mg} / \mathrm{l}$ NAA hormonal combination treatment exhibiting a shoot proliferation rate of 2.37. Macroscopic observations among the 22 treatments on shoot growth and development of explants, related to the increased size of leaves, shoot/leaves thickness, green color, vigor and robustness, obtained in media supplemented with $0.25 \mathrm{mg} / \mathrm{l} \mathrm{KIN} \mathrm{(Figure} \mathrm{1i)} \mathrm{and} 0.25 \mathrm{mg} / \mathrm{I} \mathrm{KIN}+0.05$ or $0.1 \mathrm{mg} / \mathrm{l}$ IBA (Figure 1j-1k). KIN and 2-ip caused a substantial decrease in shoot proliferation (Figure 1i-1v) in comparison to BA (Figure 1b-1h) and control (Figure 1a) (Table 1).

In the first experiment, regarding rooting, the number of roots/rooted microplant was maximum (10.08) by fortifying the MS medium with $0.25 \mathrm{mg} / \mathrm{l} \mathrm{KN}+0.1 \mathrm{mg} / \mathrm{I} \mathrm{IAA}$ (Figure 10), whereas root length was higher (37.85$39.6 \mathrm{~mm}$, almost double) in the medium with $0.25 \mathrm{mg} / \mathrm{l} \mathrm{BA}+0.05$ or $0.1 \mathrm{mg} / \mathrm{l} \mathrm{IBA}$ (Figure 1c-1d), compared to the control (6.38 roots $21 \mathrm{~mm}$ long) (Figure 1a). Root induction at $100 \%$ was achieved in the following 3 treatments: $0.25 \mathrm{mg} / \mathrm{I} \mathrm{KIN} \mathrm{(Figure} \mathrm{1i),} 0.25 \mathrm{mg} / \mathrm{I} \mathrm{KIN} \mathrm{with} 0.05 \mathrm{mg} / \mathrm{l} \mathrm{IBA}$ (Figure 1j) and $0.25 \mathrm{mg} / \mathrm{I} \mathrm{KIN}$ with 0.05 mg/l IAA (Figure 1n) (Table 2). 

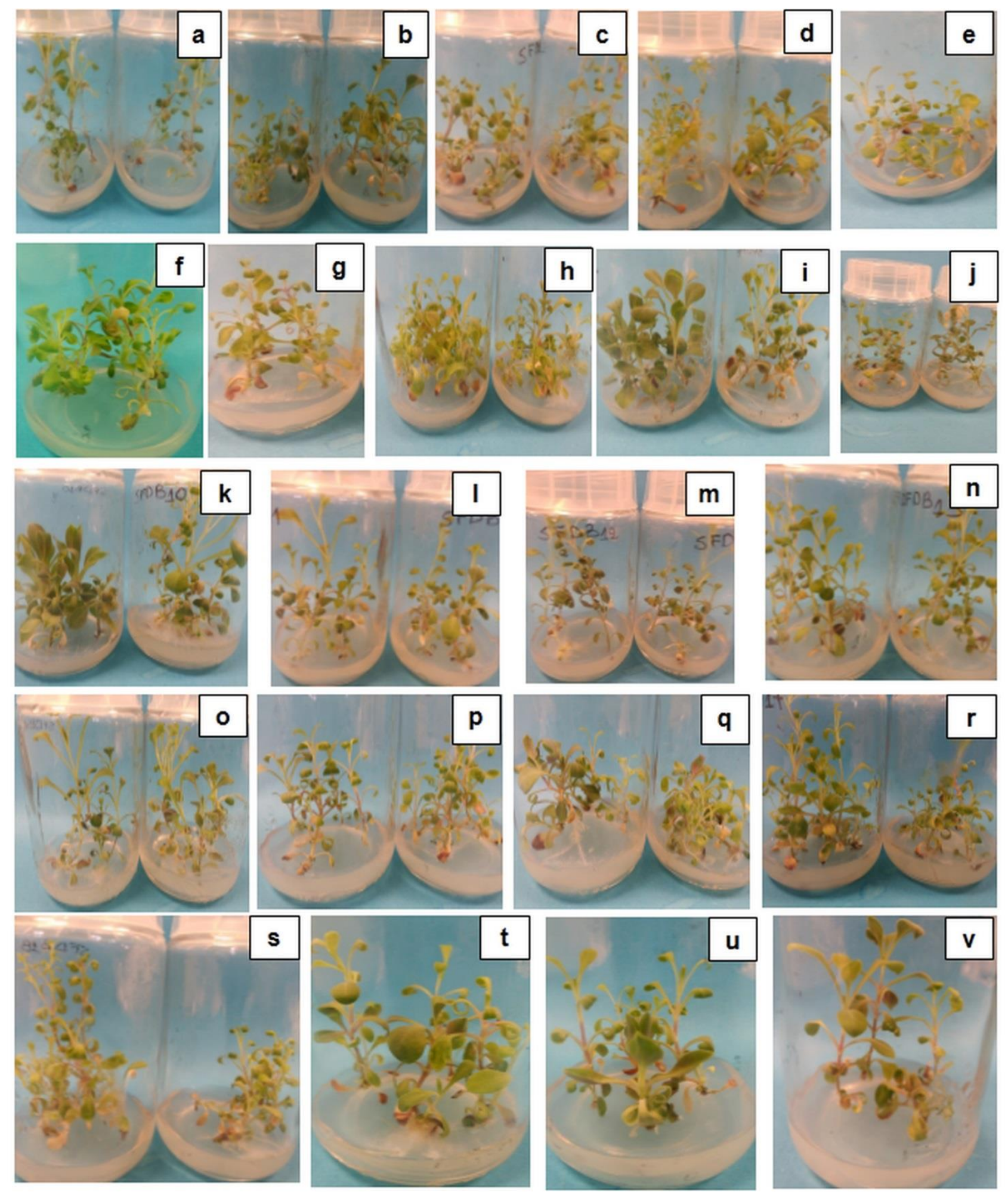

Figure 1. In vitro propagation of S. fabaria subsp. domokina explants after 5 weeks of culture in MS medium supplemented with different combinations of PGRs (mg/l): (a) Control (hormone free), (b) $0.25 \mathrm{BA}$, (c) $0.25 \mathrm{BA}$ + $0.05 \mathrm{IBA}$, (d) $0.25 \mathrm{BA}+0.1 \mathrm{IBA}$, (e) $0.25 \mathrm{BA}+0.05 \mathrm{NAA}$, (f) $0.25 \mathrm{BA}+0.1 \mathrm{NAA}$, (g) $0.25 \mathrm{BA}+0.05 \mathrm{IAA}$, (h) 0.25 $\mathrm{BA}+0.1 \mathrm{IAA}$, (i) $0.25 \mathrm{KN}$, (j) $0.25 \mathrm{KN}+0.05 \mathrm{IBA},(\mathbf{k}) 0.25 \mathrm{KN}+0.1 \mathrm{IBA}$, (l) $0.25 \mathrm{KN}+0.05 \mathrm{NAA}$, (m) $0.25 \mathrm{KN}+$ $0.1 \mathrm{NAA}$, (n) $0.25 \mathrm{KN}+0.05 \mathrm{IAA}$, (o) $0.25 \mathrm{KN}+0.1 \mathrm{IAA}$, (p) 0.25 2-ip, (q) 0.25 2-ip + $0.05 \mathrm{IBA}$, (r) 0.252 -ip + 0.1 IBA, (s) 0.25 2-ip + $0.05 \mathrm{NAA}$, (t) 0.25 2-ip + $0.1 \mathrm{NAA}$, (u) 0.25 2-ip + 0.05 IAA, (v) 0.25 2-ip + 0.1 IAA 
Table 1. Effect of $B A, K N$ and 2 -ip in combination with or without the auxins IBA, NAA and IAA on shoot proliferation of $S$. fabaria subsp. domokina after 5 weeks in culture $[P$-values from 3-way ANOVA for variables cytokinin type (A), auxin type (B), auxin concentration (C) and interactions]

\begin{tabular}{|c|c|c|c|c|}
\hline $\begin{array}{l}\text { Treatments } \\
(\mathrm{mg} / \mathrm{l})\end{array}$ & $\begin{array}{l}\text { Shoot formation } \\
\text { (\%) }\end{array}$ & $\begin{array}{l}\text { Shoot number } \\
\text { / explant }\end{array}$ & $\begin{array}{l}\text { Shoot length } \\
(\mathrm{mm})\end{array}$ & $\begin{array}{l}\text { Shoot proliferation } \\
\text { rate }\end{array}$ \\
\hline Control & $33.33 c$ & $1.33 \pm 0.14 a b$ & $66.45 \pm 5.96 \mathrm{~g}$ & $0.93 \pm 0.04 \mathrm{abcd}$ \\
\hline $0.25 \mathrm{BA}$ & $100 \mathrm{~h}$ & $3.25 \pm 0.35 \mathrm{ef}$ & $30.79 \pm 1.83 \mathrm{ab}$ & $4.08 \pm 0.47 \mathrm{fgh}$ \\
\hline $0.25 \mathrm{BA}+0.05 \mathrm{IBA}$ & $100 \mathrm{~h}$ & $2.83 \pm 0.34$ cdef & $35.21 \pm 3.15 \mathrm{abc}$ & $3.50 \pm 0.34 \mathrm{fg}$ \\
\hline $0.25 \mathrm{BA}+0.1 \mathrm{IBA}$ & $91.67 \mathrm{~h}$ & $3.67 \pm 0.67 f$ & $37.26 \pm 2.12 \mathrm{abc}$ & $4.35 \pm 0.67 \mathrm{gh}$ \\
\hline $0.25 \mathrm{BA}+0.05 \mathrm{NAA}$ & $100 \mathrm{~h}$ & $3.08 \pm 0.38 \mathrm{def}$ & $30.15 \pm 1.75 \mathrm{ab}$ & $3.50 \pm 0.44 \mathrm{fg}$ \\
\hline $0.25 \mathrm{BA}+0.1 \mathrm{NAA}$ & $91.67 \mathrm{~h}$ & $3.58 \pm 0.42 f$ & $36.25 \pm 2.63 \mathrm{abc}$ & $4.58 \pm 0.48 h$ \\
\hline $0.25 \mathrm{BA}+0.05 \mathrm{IAA}$ & $91.67 \mathrm{~h}$ & $2.82 \pm 0.30$ cdef & $27.98 \pm 1.89 a$ & $3.28 \pm 0.37 f$ \\
\hline $0.25 \mathrm{BA}+0.1 \mathrm{IAA}$ & $100 \mathrm{~h}$ & $3.67 \pm 0.45 f$ & $36.37 \pm 2.63 \mathrm{abc}$ & $4.83 \pm 0.41 \mathrm{~h}$ \\
\hline $0.25 \mathrm{KN}$ & $33.33 c$ & $1.42 \pm 0.19 \mathrm{ab}$ & $51.53 \pm 3.84$ def & $0.86 \pm 0.10 \mathrm{abc}$ \\
\hline $0.25 \mathrm{KN}+0.05 \mathrm{IBA}$ & $33.33 \mathrm{c}$ & $1.58 \pm 0.29 a b$ & $56.81 \pm 5.01$ efg & $1.00 \pm 0.11 \mathrm{abcd}$ \\
\hline $0.25 \mathrm{KN}+0.1 \mathrm{IBA}$ & $41.67 \mathrm{c}$ & $1.75 \pm 0.30 a b$ & $50.80 \pm 5.90$ def & $1.35 \pm 0.17 \mathrm{bcd}$ \\
\hline $0.25 \mathrm{KN}+0.05 \mathrm{NAA}$ & $58.33 \mathrm{e}$ & $1.67 \pm 0.19 a b$ & $42.22 \pm 4.38 \mathrm{bcd}$ & $1.41 \pm 0.09 \mathrm{bcd}$ \\
\hline $0.25 \mathrm{KN}+0.1 \mathrm{NAA}$ & $8.33 \mathrm{a}$ & $1.08 \pm 0.08 \mathrm{a}$ & $63.13 \pm 4.66 \mathrm{fg}$ & $0.21 \pm 0.02 \mathrm{a}$ \\
\hline $0.25 \mathrm{KN}+0.05 \mathrm{IAA}$ & $50 \mathrm{~d}$ & $1.92 \pm 0.29 \mathrm{abc}$ & $57.15 \pm 5.40 \mathrm{fg}$ & $1.71 \pm 0.14 \mathrm{cde}$ \\
\hline $0.25 \mathrm{KN}+0.1 \mathrm{IAA}$ & $41.67 \mathrm{c}$ & $1.50 \pm 0.19 a b$ & $50.90 \pm 5.45$ def & $1.08 \pm 0.08 \mathrm{abcd}$ \\
\hline 0.252 -ip & $41.67 \mathrm{c}$ & $1.50 \pm 0.19 a b$ & $44.58 \pm 2.11 \mathrm{cde}$ & $1.08 \pm 0.08 \mathrm{abcd}$ \\
\hline 0.252 -ip + 0.05 IBA & $75 \mathrm{~g}$ & $2.25 \pm 0.30$ bcde & $29.86 \pm 2.46 \mathrm{ab}$ & $1.88 \pm 0.28 \mathrm{de}$ \\
\hline 0.252 -ip + 0.1 IBA & $58.33 \mathrm{e}$ & $1.92 \pm 0.29 \mathrm{abc}$ & $44.31 \pm 2.77 \mathrm{cde}$ & $1.75 \pm 0.21 \mathrm{cde}$ \\
\hline $0.252-i p+0.05 \mathrm{NAA}$ & $66.67 \mathrm{f}$ & $2.17 \pm 0.37 \mathrm{abcd}$ & $37.22 \pm 4.16 \mathrm{abc}$ & $1.78 \pm 0.29 \mathrm{cde}$ \\
\hline 0.25 2-ip + 0.1 NAA & $91.67 \mathrm{~h}$ & $2.33 \pm 0.22$ bcde & $29.69 \pm 2.81 \mathrm{ab}$ & $2.37 \pm 0.31 \mathrm{e}$ \\
\hline 0.252 -ip + 0.05 IAA & $33.33 c$ & $1.75 \pm 0.37 \mathrm{ab}$ & $40.38 \pm 5.95 \mathrm{abcd}$ & $0.81 \pm 0.10 \mathrm{abc}$ \\
\hline 0.25 2-ip + 0.1 IAA & $25 \mathrm{~b}$ & $1.33 \pm 0.19 a b$ & $44.10 \pm 4.64 \mathrm{cde}$ & $0.58 \pm 0.08 \mathrm{ab}$ \\
\hline \multicolumn{5}{|l|}{$p$-values } \\
\hline Cytokinin type (A) & $0.000^{* \star \star}$ & $0.000 * \star \star$ & $0.000^{* * \star}$ & $0.000^{* * \star}$ \\
\hline Auxin type (B) & $0.180 \mathrm{~ns}$ & $0.602 \mathrm{~ns}$ & $0.361 \mathrm{~ns}$ & $0.217 \mathrm{~ns}$ \\
\hline Auxin Conc. (C) & $0.424 \mathrm{~ns}$ & $0.577 \mathrm{~ns}$ & $0.035^{*}$ & $0.074 \mathrm{~ns}$ \\
\hline$(A) *(B)$ & $0.180 \mathrm{~ns}$ & $0.233 \mathrm{~ns}$ & $0.389 \mathrm{~ns}$ & $0.000^{* \star *}$ \\
\hline$(A)^{\star}(\Gamma)$ & $0.789 \mathrm{~ns}$ & $0.012^{*}$ & $0.837 \mathrm{~ns}$ & $0.000^{* * *}$ \\
\hline$(B)^{\star}(\Gamma)$ & $0.514 \mathrm{~ns}$ & $0.815 \mathrm{~ns}$ & $0.604 \mathrm{~ns}$ & $0.834 \mathrm{~ns}$ \\
\hline$(A)^{\star}(B)^{\star}(\Gamma)$ & $0.882 \mathrm{~ns}$ & 0.662 ns & $0.000 * * *$ & $0.036^{*}$ \\
\hline
\end{tabular}


Means $\pm S . E, n=12$. Those denoted by the same letter in each column are not statistically significant different from each other according to the Duncan's multiple range test at $P \leq 0.05$, ns: $P \geq 0.05 ;{ }^{*} P \leq 0.05 ; * \star P \leq 0.001$

Table 2. Effect of BA, KN and 2-ip in combination with or without the auxins IBA, NAA and IAA on root number/ microcutting, root length $(\mathrm{mm})$ and rooting percentage of $S$. fabaria subsp. domokina after 5 weeks in culture $[P$-values from 3-way ANOVA for variables cytokinin type (A), auxin type (B), auxin concentration (C) and interactions]

\begin{tabular}{|c|c|c|c|}
\hline $\begin{array}{l}\text { Treatments } \\
(\mathrm{mg} / \mathrm{l})\end{array}$ & Root number & $\begin{array}{l}\text { Root length } \\
(\mathrm{mm})\end{array}$ & $\begin{array}{l}\text { Rooting } \\
(\%)\end{array}$ \\
\hline Control & $6.38 \pm 0.43$ defgh & $21.00 \pm 2.45$ def & $75 \mathrm{~h}$ \\
\hline $0.25 \mathrm{BA}$ & $0.00 \pm 0.00 \mathrm{a}$ & $0.00 \pm 0.00 \mathrm{a}$ & $0 \mathrm{a}$ \\
\hline $0.25 \mathrm{BA}+0.05 \mathrm{IBA}$ & $9.00 \pm 1.13 \mathrm{hij}$ & $39.60 \pm 3.46 \mathrm{~h}$ & $50 \mathrm{~g}$ \\
\hline $0.25 \mathrm{BA}+0.1 \mathrm{IBA}$ & $5.33 \pm 0.40$ cdef & $37.85 \pm 2.33 \mathrm{~h}$ & $25 d$ \\
\hline $0.25 \mathrm{BA}+0.05 \mathrm{NAA}$ & $5.25 \pm 0.31$ cdef & $16.38 \pm 0.90 \mathrm{cde}$ & $41.67 \mathrm{f}$ \\
\hline $0.25 \mathrm{BA}+0.1 \mathrm{NAA}$ & $9.33 \pm 1.05 \mathrm{ij}$ & $21.34 \pm 0.79 \mathrm{def}$ & $16.67 \mathrm{c}$ \\
\hline $0.25 \mathrm{BA}+0.05 \mathrm{IAA}$ & $4.00 \pm 0.28 \mathrm{bcd}$ & $28.70 \pm 1.60 \mathrm{~g}$ & $33.33 \mathrm{e}$ \\
\hline $0.25 \mathrm{BA}+0.1 \mathrm{IAA}$ & $6.67 \pm 0.47$ defghi & $20.56 \pm 0.09 \mathrm{def}$ & $25 d$ \\
\hline $0.25 \mathrm{KN}$ & $8.54 \pm 1.78$ ghij & $22.43 \pm 3.59$ ef & $100 \mathrm{k}$ \\
\hline $0.25 \mathrm{KN}+0.05 \mathrm{IBA}$ & $6.50 \pm 0.79$ defghi & $18.83 \pm 1.69 \mathrm{de}$ & $100 \mathrm{k}$ \\
\hline $0.25 \mathrm{KN}+0.1 \mathrm{IBA}$ & $7.30 \pm 1.30$ efghij & $26.05 \pm 5.54 \mathrm{fg}$ & $83.33 \mathrm{i}$ \\
\hline $0.25 \mathrm{KN}+0.05 \mathrm{NAA}$ & $5.90 \pm 0.77$ defg & $12.05 \pm 0.65 b c$ & $83.33 i$ \\
\hline $0.25 \mathrm{KN}+0.1 \mathrm{NAA}$ & $8.67 \pm 1.10$ ghij & $10.35 \pm 0.07 b$ & $25 d$ \\
\hline $0.25 \mathrm{KN}+0.05 \mathrm{IAA}$ & $6.42 \pm 1.50$ defgh & $15.16 \pm 1.36 \mathrm{bcd}$ & $100 \mathrm{k}$ \\
\hline $0.25 \mathrm{KN}+0.1 \mathrm{IAA}$ & $10.08 \pm 1.63 \mathrm{j}$ & $21.54 \pm 1.78 \mathrm{def}$ & $91.67 j$ \\
\hline 0.252 -ip & $2.00 \pm 0.12 a b$ & $30.84 \pm 1.13 \mathrm{~g}$ & $16.67 \mathrm{c}$ \\
\hline 0.252 -ip + 0.05 IBA & $6.75 \pm 0.57$ defghi & $20.24 \pm 1.19$ def & $33.33 \mathrm{e}$ \\
\hline 0.25 2-ip + 0.1 IBA & $6.67 \pm 0.51$ defghi & $29.56 \pm 1.45 \mathrm{~g}$ & $41.67 \mathrm{f}$ \\
\hline 0.25 2-ip + 0.05 NAA & $5.00 \pm 0.00 \mathrm{cde}$ & $22.00 \pm 0.00$ ef & $8.33 \mathrm{~b}$ \\
\hline 0.252 -ip + $0.1 \mathrm{NAA}$ & $8.00 \pm 0.96 \mathrm{fghij}$ & $16.61 \pm 1.25 \mathrm{cde}$ & $25 d$ \\
\hline 0.252 -ip + 0.05 IAA & $0.00 \pm 0.00 a$ & $0.00 \pm 0.00 \mathrm{a}$ & $0 \mathrm{a}$ \\
\hline 0.252 -ip + 0.1 IAA & $3.00 \pm 0.00 \mathrm{bc}$ & $36.67 \pm 0.00 \mathrm{~h}$ & $8.33 \mathrm{~b}$ \\
\hline \multicolumn{4}{|l|}{$p$-values/3-way ANOVA } \\
\hline Cytokinin type (A) & $0.000^{* * *}$ & $0.000^{\star * \star}$ & $0.000^{* * *}$ \\
\hline Auxin type (B) & $0.000 * * *$ & $0.000^{\star * *}$ & $0.022^{*}$ \\
\hline Auxin Concentration (C) & $0.000^{* * *}$ & $0.000^{* * *}$ & $0.445 \mathrm{~ns}$ \\
\hline$(A)^{*}(B)$ & $0.000^{* * *}$ & $0.000^{\star * \star}$ & $0.209 \mathrm{~ns}$ \\
\hline$(A)^{\star}(\Gamma)$ & $0.377 \mathrm{~ns}$ & $0.000^{\star \star \star}$ & $0.060 \mathrm{~ns}$ \\
\hline
\end{tabular}




\begin{tabular}{|l|l|l|l|}
\hline$(B)^{\star}(\Gamma)$ & $0.000^{\star \star \star}$ & $0.000^{\star \star \star}$ & $0.045^{\star}$ \\
\hline$(\mathrm{A})^{\star}(\mathrm{B})^{\star}(\Gamma)$ & $0.180 \mathrm{~ns}$ & $0.000^{\star \star \star}$ & $0.315 \mathrm{~ns}$ \\
\hline
\end{tabular}

Means \pm S.E, $n=12$. Those denoted by the same letter in each column are not statistically significant different from each other according to the Duncan's multiple range test at $P \leq 0.05$, ns: $P \geq 0.05$; ${ }^{*} \leq 0.05$; ${ }^{* * *} P \leq 0.001$

In the second experiment, root number was maximum ( 9.75 roots/rooted microplant) with $0.5 \mathrm{mg} / \mathrm{l} \mathrm{NAA}$ (almost double) in relation to the control. The other 2 auxin types, IBA and IAA (irrespective of concentration) gave similar root numbers (4.57-5.73) to the control (4.6 roots). However, the 2 lowest applied NAA concentrations ( 0.1 and $0.25 \mathrm{mg} / \mathrm{l}$ ) caused a 2.3 to 2.6 -fold decrease in root number from 4.6 (control) to $1.75-2$. Root length was greatest by adding either $0.5 \mathrm{mg} / \mathrm{IIBA}(24.15 \mathrm{~mm})$ or $0.1 \mathrm{mg} / \mathrm{l} \mathrm{IAA}(24.59 \mathrm{~mm})$, increased by $0.5 \mathrm{~cm}$ with respect to the control. NAA, on the other hand, irrespective of concentration diminished root length from 19.13 $\mathrm{mm}$ (control) to $5-9.46 \mathrm{~mm}$ (decrease by $1-1.4 \mathrm{~cm}$ ). Rooting $100 \%$ was achieved in the following 4 treatments: IBA $(0.1$ and $0.25 \mathrm{mg} / \mathrm{l})$, and IAA $(0.25$ and $0.5 \mathrm{mg} / \mathrm{l})$. NAA gave low rooting percentages (12.5-25\%) compared to the control (3.75-7.5 decrease). Root morphology of explants treated with IBA and IAA was similar; white colored roots of sufficient thickness and length, harsh texture, without lint and absence of radical hairs over the main/primary roots. However, NAA gave roots of different morphology and lower quality than IBA and IAA; compact fluffy roots, extremely short of soft texture with numerous radical hair roots. Among the 3 auxin types, IBA was the most effective for rooting of $S$. fabaria ssp. domokina shoot tip explants, IAA recorded intermediate results and NAA was the least effective. Therefore, the best rooting treatment was $0.1 \mathrm{mg} / \mathrm{l} I \mathrm{IBA}$, taking simultaneously all attributes into consideration (Table 3).

Table 3. Effect of auxin type (IBA, NAA, IAA) and concentration $(0,0.1,0.25,0.5 \mathrm{mg} / \mathrm{l})$ on rooting percentage (\%), root number/rooted microcutting and root length $(\mathrm{mm})$ in $S$. fabaria subsp. domokina shoot-tip explants after 4 weeks of in vitro culture [ $P$-values from 2-way ANOVA for variables auxin type $(\mathrm{A})$, auxin concentration (B) and their interaction $\left.\left(A^{*} B\right)\right]$

\begin{tabular}{|c|c|c|c|}
\hline $\begin{array}{l}\text { Treatments } \\
(\mathrm{mg} / \mathrm{l})\end{array}$ & $\begin{array}{l}\text { Rooting } \\
(\%)\end{array}$ & Root number & $\begin{array}{l}\text { Root length } \\
(\mathrm{mm})\end{array}$ \\
\hline Control & $93.75 \mathrm{c}$ & $4.60 \pm 0.57 b$ & $19.13 \pm 1.75 \mathrm{~cd}$ \\
\hline $0.1 \mathrm{IBA}$ & $100 \mathrm{~d}$ & $5.73 \pm 0.60 \mathrm{~b}$ & $22.91 \pm 1.45 \mathrm{de}$ \\
\hline 0.25 IBA & $100 \mathrm{~d}$ & $5.31 \pm 0.51 b$ & $21.66 \pm 1.74 \mathrm{cde}$ \\
\hline $0.5 \mathrm{IBA}$ & $93.75 \mathrm{c}$ & $4.83 \pm 0.42 b$ & $24.15 \pm 1.17 \mathrm{e}$ \\
\hline $0.1 \mathrm{NAA}$ & $25 \mathrm{~b}$ & $1.75 \pm 0.06 a$ & $8.13 \pm 0.27 \mathrm{ab}$ \\
\hline $0.25 \mathrm{NAA}$ & $12.5 \mathrm{a}$ & $2.00 \pm 0.09 a$ & $5.00 \pm 0.00 a$ \\
\hline $0.5 \mathrm{NAA}$ & $25 \mathrm{~b}$ & $9.75 \pm 0.42 c$ & $9.46 \pm 0.14 b$ \\
\hline $0.1 \mathrm{IAA}$ & $93.75 \mathrm{c}$ & $4.57 \pm 0.43 b$ & $24.59 \pm 2.04 \mathrm{e}$ \\
\hline 0.25 IAA & $100 d$ & $5.20 \pm 0.37 b$ & $22.09 \pm 1.08 \mathrm{de}$ \\
\hline $0.5 \mathrm{IAA}$ & $100 \mathrm{~d}$ & $5.13 \pm 0.76 b$ & $18.03 \pm 1.61 \mathrm{c}$ \\
\hline \multicolumn{4}{|l|}{$P$-values } \\
\hline Auxin type (A) & $0.000^{* \star *}$ & $0.226 \mathrm{~ns}$ & $0.000^{* * *}$ \\
\hline Auxin Concentration (B) & $0.000^{\star * \star}$ & $0.000^{* \star *}$ & $0.056 \mathrm{~ns}$ \\
\hline$(A)^{\star}(B)$ & $0.000^{* * *}$ & $0.000 * * *$ & $0.000^{* * *}$ \\
\hline
\end{tabular}


Means \pm S.E. with the same letter in a column are not statistically significant different from each other according to the Duncan's multiple range test at $P \leq 0.05$. ns: $P \geq 0.05$, ${ }^{* *} P \leq 0.001$

In the second experiment, all 3 auxins did not differentiate shoot number (1-1.13 shoots/explant) and shoot proliferation rate (2.63-3.56) to a considerable degree in comparison to the control (1.19 shoots/explant, 3.19 proliferation rate). Shoot length was greatest $(80.63 \mathrm{~mm})$ with $0.5 \mathrm{mg} / \mathrm{I}$ IAA and enhanced by $1.3 \mathrm{~cm}$ related to the control's $(67.19 \mathrm{~mm})$, whereas all the other treatments gave similar results. Shoot multiplication percentage was higher (18.75\%) in the control explants (Table 4).

The survival percentage of rooted microplants acclimatized within 4 weeks in the mist system was $92.31 \%$. The vegetative growth and development of plants within this 4 -week period was substantially enhanced. The percentage of successfully acclimatized plants that achieved to survive throughout subsequent transplantations to 0.33 and $2.5 \mathrm{~L}$ pots was $100 \%$. The whole acclimatization and hardening process of S. fabaria subsp. domokina from in vitro rooted plantlets to hardened potted plants in the nursery outdoors, was completed within a 16week period (mid-February until the end of May 2018) (Figure 2a-2c).

Table 4. Effect of auxin type (IBA, NAA, IAA) and concentration $(0,0.1,0.25,0.5 \mathrm{mg} / \mathrm{l})$ on shoot formation percentage (\%), shoot number/explant, shoot length $(\mathrm{mm})$ and shoot proliferation rate in $S$. fabaria subsp. domokina shoot-tip explants after 4 weeks of in vitro culture [ $P$-values from 2-way ANOVA for variables auxin type $(A)$, auxin concentration $(B)$ and their interaction $\left.\left(A^{*} B\right)\right]$

\begin{tabular}{|l|l|l|l|l|}
\hline $\begin{array}{l}\text { Treatments } \\
(\mathrm{mg} / \mathrm{l})\end{array}$ & $\begin{array}{l}\text { Shoot formation } \\
(\%)\end{array}$ & Shoot number & $\begin{array}{l}\text { Shoot length } \\
(\mathrm{mm})\end{array}$ & $\begin{array}{l}\text { Shoot proliferation } \\
\text { rate }\end{array}$ \\
\hline Control & $18.75 \mathrm{~d}$ & $1.19 \pm 0.10 \mathrm{a}$ & $\begin{array}{l}67.19 \pm 4.38 \\
\mathrm{ab}\end{array}$ & $3.19 \pm 0.21 \mathrm{ab}$ \\
\hline $0.1 \mathrm{IBA}$ & $12.5 \mathrm{c}$ & $1.13 \pm 0.09 \mathrm{a}$ & $76.25 \pm 4.07 \mathrm{bc}$ & $3.56 \pm 0.22 \mathrm{~b}$ \\
\hline $0.25 \mathrm{IBA}$ & $6.25 \mathrm{~b}$ & $1.06 \pm 0.06 \mathrm{a}$ & $75.16 \pm 3.78 \mathrm{bc}$ & $3.47 \pm 0.24 \mathrm{~b}$ \\
\hline $0.5 \mathrm{IBA}$ & $12.5 \mathrm{c}$ & $1.13 \pm 0.09 \mathrm{a}$ & $73.59 \pm 3.98 \mathrm{bc}$ & $3.22 \pm 0.27 \mathrm{ab}$ \\
\hline $0.1 \mathrm{NAA}$ & $6.25 \mathrm{~b}$ & $1.06 \pm 0.06 \mathrm{a}$ & $59.53 \pm 2.98 \mathrm{a}$ & $2.63 \pm 0.17 \mathrm{a}$ \\
\hline $0.25 \mathrm{NAA}$ & $0 \mathrm{a}$ & $1.00 \pm 0.00 \mathrm{a}$ & $72.19 \pm 2.81 \mathrm{bc}$ & $3.13 \pm 0.21 \mathrm{ab}$ \\
\hline $0.5 \mathrm{NAA}$ & $0 \mathrm{a}$ & $1.00 \pm 0.00 \mathrm{a}$ & $70.94 \pm 2.82 \mathrm{bc}$ & $2.94 \pm 0.25 \mathrm{ab}$ \\
\hline 0.1 IAA & $6.25 \mathrm{~b}$ & $1.06 \pm 0.06 \mathrm{a}$ & $77.81 \pm 3.98 \mathrm{bc}$ & $3.44 \pm 0.27 \mathrm{~b}$ \\
\hline 0.25 IAA & $0 \mathrm{a}$ & $1.00 \pm 0.00 \mathrm{a}$ & $75.31 \pm 2.07 \mathrm{bc}$ & $2.94 \pm 0.18 \mathrm{ab}$ \\
\hline 0.5 IAA & $0 \mathrm{a}$ & $1.00 \pm 0.00 \mathrm{a}$ & $80.63 \pm 3.68 \mathrm{c}$ & $3.56 \pm 0.23 \mathrm{~b}$ \\
\hline P-values & & & & \\
\hline Auxin type (A) & $0.000^{\star \star *}$ & $0.335 \mathrm{~ns}$ & $0.010^{\star \star}$ & $0.035^{\star}$ \\
\hline Auxin Concentration (B) & $0.000^{\star \star *}$ & $0.017^{*}$ & $0.041^{*}$ & $0.987 \mathrm{~ns}$ \\
\hline (A) ${ }^{\star}(\mathrm{B})$ & $0.000^{\star \star *}$ & $0.981 \mathrm{~ns}$ & $0.139 \mathrm{~ns}$ & $0.117 \mathrm{~ns}$ \\
\hline
\end{tabular}

Means \pm S.E. with the same letter in a column are not statistically significant different from each other according to the Duncan's multiple range test at $P \leq 0.05$. ${ }^{*} P \leq 0.05$, ${ }^{* * P} \leq 0.01,{ }^{* * * P} \leq 0.001$ 

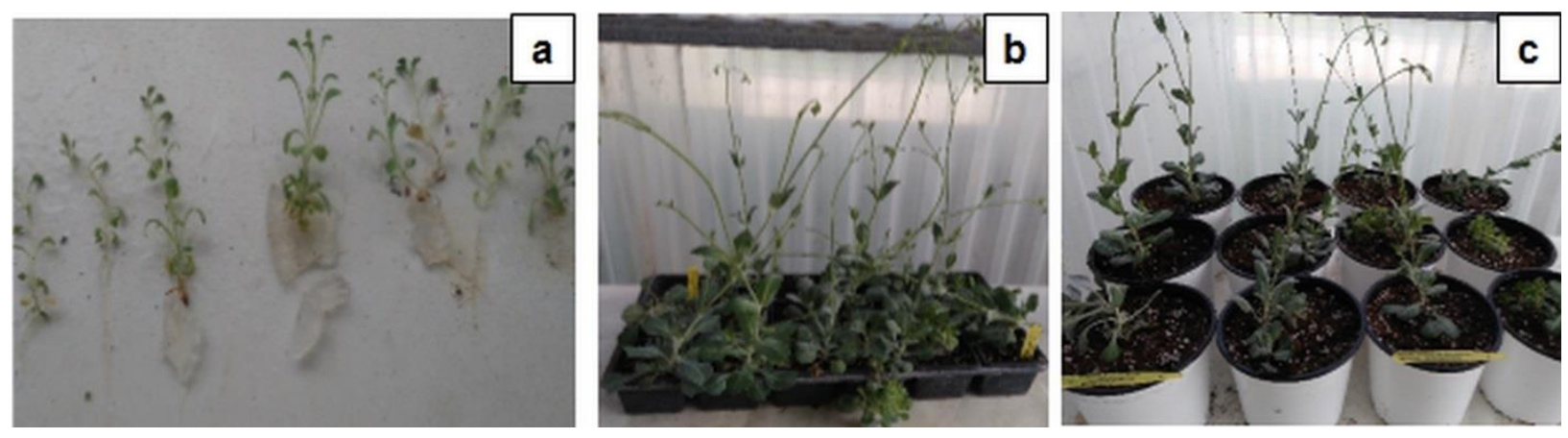

Figure 2. Acclimatization of the in vitro rooted S. fabaria subsp. domokina plantlets in unheated greenhouse conditions. (a) rooted microplants prior transplanting in a peat moss (Terrahum): perlite (1:1 v/v) substrate and transfer into plastic tunnel fog system in mid-February $(\mathbf{b}, \mathbf{c})$ transplantation of acclimatized plantlets after 4 weeks in pots of $0.33 \mathrm{Lt}$ and after another 7 weeks in $2.5 \mathrm{~L}$ pots, respectively, containing a peat moss (TS2, Clammann): perlite: soil $(2: 1 / 2: 1 / 2 \mathrm{v} / \mathrm{v})$ substrate and transferred on a greenhouse bench with $50 \pm 5 \%$ relative humidity and irrigated by sprinkling

\section{Discussion}

Modern biotechnology tools including micropropagation can be a safeguard measure against the increasing loss of wild populations in the nature, providing higher yield, commercial utilization potential on a commercial basis, improved genetic characteristics, production of clonal plants and preservation of germplasm [29]. In general, cytokinins and auxins are important plant growth regulators (PGRs) in tissue culture systems as the former is primarily required for production of multiple shoots and the later mainly for root formation [30].

Cytokinins are used for the induction of both adventitious and axillary shoots from meristenatic explants by inhibiting or decreasing the apical meristem dominance [31]. It has been reported on various Silene species that PGRs supplemented to the culture medium improve the number of shoots and shoot length [20-22]. The combination treatment $0.25 \mathrm{mg} / \mathrm{l} \mathrm{BA}+0.1 \mathrm{mg} / \mathrm{l} \mathrm{IAA}$ proved to be the best for the initial shoot induction phase of $S$. fabaria subsp. domokina explants in the current study. Dixon and Gonzales [32] reported that the two main categories of PGRs, cytokinins and auxins are required in combination in tissue culture media as they can alter the growth response of plant cultures based on their variation levels. In another Silene species (S. leucophylla), a maximum shoot production (150 shoots/single explant) was achieved on MS medium supplemented with 4.5 $\mathrm{mg} / \mathrm{l} \mathrm{BA}, 0.5 \mathrm{~g} / \mathrm{l}$ casein and $0.5 \mathrm{mg} / \mathrm{l}$ silver nitrate [33]. It is worth mentioning that among the different cytokinin types, BA is the most effective, low cost and preferable cytokinin used for the shoot proliferation stage [34].

In the first experiment, the addition of high concentrations of cytokinins with and without auxins had a negative effect on shoot length of $S$. fabaria explants, therefore for the subsequent shoot elongation phase, the MS hormone-free medium proved to be the most effective. Similarly, Buishing et al. [35] experimenting with soybean observed an inhibition in the elongation of adventitious meristems when higher BA concentrations were used. Different results have been reported for a Silene hybrid (S. polypetala $\times$ S. virginica) where the MS basal medium supplemented with $1 \mathrm{mg} / \mathrm{l} \mathrm{BA}$ appeared to be optimal for the massive production of non-vitreous shoots with sufficient length [21]. In the second experiment of our study, however the addition of the auxin IAA at $0.5 \mathrm{mg} / \mathrm{I}$ stimulated further the elongation of the proliferated shoots $(80.63 \mathrm{~mm})$ in comparison to cytokinin + auxin hormonal combinations of the first experiment $(27.98-63.13 \mathrm{~mm})$ and the controls of both experiments conducted (66.45-67.19 mm).

In the current study, BA was the most effective cytokinin type for shoot proliferation of $S$. fabaria microplants in comparison to kinetin and 2-ip, applied in combination with or without the addition of IBA and NAA. In another study, Buah et al. [36] demonstrated that each cytokinin type displays specific relative strength in the ability of explants for multiple shoot induction, depending on several factors including mobility, stability, conjugation and oxidation rate as well as interaction with other PGRs present in the medium. In consistency with our results in $S$. 
fabaria and according to Rajasekhar and Nair [37] in diploid and triploid Musa cultivars, BA showed better shoot formation performance probably due to its higher stability in comparison to the other two cytokinins, kinenin and 2-ip. The same authors postulated that both conjugation rate and breakdown of BA in the culture medium are lower and slower, thus maintaining its activity for a longer period, being readily available to plant tissues in larger amounts in free or ionized forms than the other cytokinin types. In S. bolanthoides Quezel, Contandr. \& Pamukc., the highest number of regenerated shoots (5.75) was obtained from nodal explants that were cultured on MS medium with $2 \mathrm{mg} / \mathrm{l} \mathrm{BA}$ and $0.1 \mathrm{mg} / \mathrm{I} \mathrm{NAA} \mathrm{[38].} \mathrm{With} \mathrm{respect} \mathrm{to} S$. fabaria explants under experimentation, $B A$ is the most suitable cytokinin type, regardless auxin type for shoot proliferation. BA in combination with NAA has been the most widely used for promoting shoot induction and multiplication in Silene species [24-26]. KIN and 2-ip, on the other hand led to a decline in shoot number and shoot multiplication percentage, therefore are not appropriate cytokinin types for in vitro shoot proliferation for $S$. fabaria under study.

In the present study, the application of BA + IBA had a positive effect on initial shoot proliferation (3.67 shoot number, $100 \%$ shoot formation percentage) and root elongation $(37.85-39.6 \mathrm{~mm})$ of $\mathrm{S}$. fabaria microplants. It is widely known the necessity of supplementing the culture medium with a low concentration of auxin along with a cytokinin, both in optimum quantities for obtaining higher rate of shoot multiplication [19]. In consistency with our findings, in another Silene species (S. cretacea), basic Woody Plant Medium (WPM) containing vitamins according to MS medium and supplemented with $0.2 \mathrm{mg} / \mathrm{l} \mathrm{BA}, 1 \mathrm{mg} / \mathrm{l} \mathrm{KIN}, 1 \mathrm{mg} / \mathrm{l} \mathrm{GA}$, and $0.5 \mathrm{mg} / \mathrm{I} \mathrm{IBA}$ was the most effective at shoot proliferation and rooting stages in one step [20]. The maintenance of balance between inorganic and organic constituents in the culture medium is a prerequisite factor for the growth of plant cells/tissues and is regulated by different hormones applied either individually or in combination defining explants' subsequent differentiation and development either into shoots or roots or both [39]. Accordingly, the most suitable medium for both shoot proliferation and rooting of S. eviscosa and S. schischkinii was the MS supplemented with $0.1 \mathrm{mg} / \mathrm{l} \mathrm{KIN}$ and $0.2 \mathrm{mg} / \mathrm{l} \mathrm{GA} 3$ [40].

With respect to the studied S. fabaria, best rooting results were also obtained by incorporating $0.1 \mathrm{mg} / \mathrm{I}$ IBA ( 5.73 roots $22.91 \mathrm{~mm}$ long, 100\% rooting) into the MS medium after a 4-week period of culture. The optimal medium for rooting of 4 Silene species (S. fetissovii, S. obovata, S. sussamyrica and S. ladyginae) was the MS with the addition of $1 \mathrm{mg} / \mathrm{IIAA}$ [40]. On the other hand, in S. bolanthoides Quezel, Contandr. \& Pamukc. regenerated shoots were rooted on PGRs-free MS medium [38]. S. fabaria explants under study yielded better rooting performance when treated with $0.1 \mathrm{mg} / \mathrm{IBA}$ followed by KIN + auxins hormonal combinations. Our findings are up to a point in agreement with those obtained in S. leucophylla, wherein the MS medium fortified with $4 \mathrm{mg} / \mathrm{l}$ $\mathrm{BA}, 0.4 \mathrm{mg} / \mathrm{l} \mathrm{NAA}, 0.2 \mathrm{mg} / \mathrm{GA}_{3}, 200 \mathrm{mg} / \mathrm{l}$ adenine sulfate, $0.5 \mathrm{mg} / \mathrm{l}$ silver nitrate and $0.5 \mathrm{~g} / \mathrm{l}$ casein favored rooting of the proliferated shoots [33]. IAA is the most widely known endogenous auxin but with the highest oxidation rate compared to the other natural IBA, or the synthetic NAA auxins [41, 42]. In particular, previous investigations on eucalyptus revealed the existence of differences in the stability of IBA and IAA as depicted by their performance in root formation [43], thus, IBA is highly stable in plant tissues and the most widely used auxin for root induction [42].

In this study, the establishment of a complete direct in vitro propagation protocol of S. fabaria subsp. domokina was described using shoot-tip explants in order to obtain clonal plants for the creation of mother plantations and maintenance of microplants, to have adequate material to use in future studies.

\section{Conclusions}

In vitro propagation of medicinal plants with enriched bioactive principles is found to be highly useful for commercial production of medicinally important compounds. Reintroduction and reinforcement programs targeting to the protection of wild populations under extinction and creation of plant propagating material and mother plantations can be achieved via ex situ conservation methods. In the present study, an effective disinfection protocol was obtained $(90.91 \%)$, followed by an extremely rapid increase ( 6 -fold) in the number of proliferated shoots within a 3-month period. For the initial establishment stage, the MS medium supplemented with $0.25 \mathrm{mg} / \mathrm{l} \mathrm{BA}, 0.1 \mathrm{mg} / \mathrm{l} \mathrm{IBA}$ and $0.1 \mathrm{mg} / \mathrm{l} \mathrm{GA}$ was effective. The hormonal combination $0.25 \mathrm{mg} / \mathrm{l} \mathrm{BA}+0.1$ $\mathrm{mg} / \mathrm{l}$ IAA is proposed for the initial shoot induction stage (100\% shoot formation, 4.83 proliferation rate) (5 
weeks), $0.5 \mathrm{mg} / \mathrm{I}$ IAA for the elongation of the proliferated shoots, and $0.1 \mathrm{mg} / \mathrm{l} \mathrm{IBA}$ for rooting (100\%) (4 weeks). The ex vitro acclimatization of rooted vitroplants was successful with $92.31 \%$ survival rate, during the whole 16 week period (mid-February until the end of May 2018). This is the first efficient and reusable micropropagation protocol of medicinal-ornamental S. fabaria subsp. domokina established to address increased demand, germplasm conservation and future genetic engineering goals.

\section{Conflicts of Interest}

The authors declare no conflict of interest in this work

\section{Aknowledgements}

The postdoctoral research and scientific publication was carried out within the framework "STRENGTHENING OF POSTDOCTORAL RESEARCHERS" of the OP "Development of Human Resources, Education and Lifelong Learning", 2014-2020, which is being implemented from the National Scholarships Foundation (NSF) in Greece, and is co-funded by the European Social Fund and the Hellenic Republic.

\section{References}

1. CBD Secretariat (2000) Global strategy for plant conservation. http://www.cbd.int/gspc/ May 2000.

2. Popp M (2008) New combinations in Lychnis (Caryophyllaceae) from Africa. Novon: A J. Botanic Nomenclature 18:99-100

3. Jiang L, Dunn BL, Wang YW, Goad CL (2016) Responses to propagation substrate and rooting hormone products to facilitate asexual propagation of Silene chalcedonica and Silene coronaria. J Environ Hortic 34(3):80-83

4. Steffey J (1986) Strange relatives the pink family. J Am Hortic 65(6):4-9

5. Dimopoulos P, Raus Th, Bergmeier E, Constantinidis Th, latrou G, Kokkini S. Strid A, Tzanoudakis D (2013) Vascular plants of Greece: An Annotated Checklist. Englera 31. Botanischer Garten und Botanisches Museum Berlin-Dahlem, Freie Universität Berlin / Hellenic Botanical Society, Athens

6. Dimopoulos P, Raus Th, Bergmeier E, Constantinidis Th, latrou G, Kokkini S, Strid A, Tzanoudakis D (2016) Vascular plants of Greece: An annotated checklist. Supplement. Willdenowia 46(3):301-347

7. Krishnamurthi S, Chadha Y (1972) The Wealth of India. CSIR: New Delhi, India, pp 177-183

8. Ballero M, Fresu I (1993) Le piante di uso officinale nella Barbagia di Seui (Sardegna Centrale). Fitoterapia 64:141-150

9. Hirst M (1997) A river of metaphors: Interpreting the Xhosa diviner's myth. Afr Stud 56(2):217-250

10. Rongping Z, Cheng Z, Yineng H, Ninghua T, Jun Z (1997) Three new cyclopeptides from Silene szechuensis. Acta Bot Yunn 19(3):304-310

11. Ali Z, Ahmad VU, Ali MS, Iqbal F, Zahid M, Alam N (1999) Two new C-Glycosylflavones from Silene conoidea. Nat Prod Lett 13:121-129

12. Golovko V, Bushneva $O$ (2007) Stabilizing effect of Silene pectin polysaccharide on electrical activity of the sinoatrial area in frog heart. Bull Exp Biol Med143:284-286

13. Sobiecki J (2008) A review of plants used in divination in southern Africa and their psychoactive effects. South Afr Human 20:333-351

14. Wink M (2010) Annual plant reviews, functions and biotechnology of plant secondary metabolites, WileyBlackwell: Chichester, UK, pp 424 
15. Wink M (2011) Annual plant reviews, biochemistry of plant secondary metabolism, Wiley-Blackwell: Chichester, UK, pp 464

16. Strid A (2016) Atlas of the Aegean flora. Part 2: maps. Englera 33(2):1-878

17. Greuter W (1995) Studies in Greek Caryophylloideae: Agrostemma, Silene, and Vaccaria. Willdenowia 25:105-142

18. Benson EE, Danaher JE, Pimbley IM, Anderson CT, Wake JE, Daley S, Adams LK (2000) In vitro micropropagation of Primulan scotica: a rare Scottish plant. Biodivers Conserv 9(6):711-726

19. Rout GR, Samantaray S, Das P (2000) In vitro manipulation and propagation of medicinal plants. Biotechnol Adv 18:91-120

20. Kritskaya TA, Kashin AS, Spivak VA, Firstov VE (2016) Features of clonal micropropagation of Silene cretacea (Caryophyllaceae) in in vitro culture. Russ J Dev Biol 47(6):359-366

21. Ault JR (1992) In vitro propagation of a Silene Hybrid (S. polypetala x S. virginica). HORTSCIENCE 27(11):1226

22. Erdoğan U (2010) Tehlike altındaki Silene sangaria Coode \& Cullen'nin mikrocoğaltımı [dissertation]. [Turkey]: Institute of Natural and Applied Sciences, Trakya University, pp 90

23. Hanus-Fajerska E, Czura A, Grabski K, Tukaj Z (2009) The effect of conditioned medium obtained from Scenedesmus subspicatus on suspension culture of Silene vulgaris (Caryophyllaceae). Acta Physiol Plant 31:881-887

24. Jack EM, Anatasova S, Verkleij JAC (2005) Callus induction and plant regeneration in the metallophyte Silene vulgaris (Caryophyllaceae). Plant Cell Tiss Organ Cult 80:25-31

25. Cafuir L, Antonovics J, Hood ME (2007) Tissue culture and quantification of individual level resistance to anther-smut disease in Silene vulgaris. Int J Plant Sci 168(4):415-419

26. Panayotova LG, Ivanova TA, Bogdanova YY, Stoeva TD (2008) In vitro cultivation of plant species from sandy dunes along the Bulgarian Black Sea Coast. Phytol Balcan 14(1):119-123

27. North J, Ndakidemi P, Laubscher CP (2010) The potential of developing an in vitro method for propagating Strelitziaceae. Afr J Biotechnol 9(45):7583-7588

28. Murashige T, Skoog F (1962) A revised medium for rapid growth and bioassays with tobacco tissue cultures. Physiol Plant 15(3):473-497

29. Teshome I, Teshome S, Soromessa T, Feyissa T (2016) Development of an efficient in vitro propagation protocol for Satureja punctata - A rare aromatic and medicinal plant. Taiwania 61(1):41-48

30. North J, Ndakidemi P, Laubscher CP (2012) Effects of antioxidants, plant growth regulators and wounding on phenolic compound excretion during micropropagation of Strelitzia reginae. Int J Phys Sci 7(4):638646

31. Pandey S, Jaiswal VS (2002) Micropropagation of Terminalia arjuna Roxb. from cotyledonary nodes. Indian J Exp Biol 40(8):950-953.

32. Dixon RA, Gonzales RA (1994) Plant cell culture: A practical approach, 2nd edn. Oxford University Press, Oxford

33. Saker M, El-Demerdash M, Allam MA (2011) In vitro propagation and genetic characterization as effective tools for conservation of Silene leucophylla, grown in St. Katherine Protected Area, Sinai, Egypt. J Gen Engin Biotechnol 9:21-27

34. Johnson M, Manickam VS (2003) In vitro micropropagation of Baliospermum montanum (Willd.) MuellArg-a medicinal plant. Indian J Exp Biol 41(11):1349-1351 
35. Buising CM, Shoemaker RC, Benbow RM (1994) Early Events of multiple bud formation and shoot development in soybean embryonic axes treated with the cytokinin, 6-benzylaminopurine. Am J Bot 81(1):1435-1448

36. Buah JN, Danso E, Taah KJ, Abole EA, Bediako EA, Asiedu J, Baidoo R (2010) The effects of different concentrations cytokinins on the in vitro multiplication of plantain (Musa sp.). Biotechnology 9(3):343-347

37. Rajasekhar R, NairAS (2011) Differential effect of cytokinins in the micropropagation of diploid and triploid Musa cultivars. Int J Integrative Biol 11(1):35-38

38. Corduk N, Yucel G, Akınc N, Tuna M, Esen O (2018) In vitro propagation of Silene bolanthoides Quézel, Contandr. \& Pamukç. and assessment of genetic stability by flow cytometry. Arch Biol Sci 70(1):141-148

39. Haq I, Dahot MU (2007) Morpho-physiological aspects of micro-propagating banana under different hormonal conditions. Asian J Plant Sci 6(3):496-501

40. Umralina AR (2013) In vitro culture introduction of Silene genus of Caryophyllaceae family endemic species. KazNU Bull. Biol series №2 58:55-60

41. De Klerk GJ, van der Krieken W, De Jong J (1999) The formation of adventitious roots: new concepts, new possibilities. In Vitro Cell Dev Biol-Plant 35:189-199

42. George EF, Hall MA, De Klerk GJ (2008) Plant propagation by tissue culture, 3rd edn. Springer, The Netherlands, pp 104-204

43. Nakhooda M, Watt MP, Mycock D (2011) Auxin stability and accumulation during in vitro shoot morphogenesis influences subsequent root induction and development in Eucalyptus grandis. Plant Growth Regul 65:263-271 